\title{
Derajat keparahan infeksi Soil Transmitted Helminths terhadap status gizi dan anemia pada anak sekolah dasar
}

\author{
Severity of Soil Transmitted Helminths infection with nutritional status and anemia in elementary school \\ student
}

Farissa Fatimah ${ }^{1}$, Sri Sumarni², Muhammad Juffrie ${ }^{3}$

\begin{abstract}
Backgound: Indonesia as a tropical country with high humidity, has good environment for worm breeding particularly Soil Transmitted Helminths (STH). The prevalence of worm infestation in Indonesia is still relatively high, about $60 \%$ of 220 million Indonesian population, 21\% of them are elementary school-age children. STH intensity greatly affects the nutritional status of patients, in wich more severe infection leads to poorer nutrition condition.

Objective: To identify severity of STH infection in elementary school student at the working area of Kokap I Health Center of Kulonprogo and its correlation with nutritional status and anemia.

Method: The study was undertaken in 25 elementary schools at the working area of Kokap I Health Center of Kulonprogo. Samples were all students of grade I as many as 241 students. Worm examination was done by using Kato-Katz method, assessment of nutrition status was based on body weight according to height (weight/height), anemia status was assessed from $\mathrm{Hb}$ level using Cyanmethaemoglobin method.

Results: The results of the study showed that most of students (83,6\%) were well nourished and were non anemic (84,9\%). No student belonged to severe anemic category, 3 students (1,3\%) had anemia at medium category and 31 students (13,8\%) were slightly anemic. Out of 51 students that positively got STH infection, 16 students (31.4\%) had light infection of A. lumbricoides, 36 students (70,6\%) had T. trichiura and 4 students (5,9\%) had hookworm. A. lumbricoides infected 7 student (13,7\%) and T. trichiura infected 8 student $(15,7 \%)$ both at medium criteria. There was no infection at severe criteria. The result of Somers' $D$ analysis showed that there was no significant correlation between the two variables $(p>0,05)$.

Conclusion: There was no correlation between severity of STH infections with nutrition status and anemia in elementary school student.
\end{abstract}

KEY WORDS: Soil Transmitted Helminths infection, nutrition status, anemia

\begin{abstract}
ABSTRAK
Latar belakang: Indonesia sebagai salah satu negara tropis dengan kelembapan tinggi mempunyai lingkungan yang baik untuk perkembangbiakan cacing terutama Soil Transmitted Helminths (STH). Prevalensi kecacingan di Indonesia masih cukup tinggi yaitu sekitar $60 \%$ dari 220 juta penduduk dan $21 \%$ diantaranya menyerang anak usia sekolah dasar. Derajat atau intensitas STH sangat mempengaruhi keadaan gizi penderita, semakin berat infeksi maka keadaan gizi penderita semakin buruk, hal ini juga bisa menyebabkan anemia.

Tujuan: Mengetahui derajat keparahan infeksi STH pada anak sekolah dasar di wilayah kerja Puskesmas Kokap I, Kabupaten Kulonprogo serta hubungannya dengan status gizi dan anemia.

Metode: Penelitian dilakukan di 25 sekolah dasar yang berada di wilayah kerja Puskesmas Kokap I Kabupaten Kulonprogo dengan sampel seluruh siswa kelas 1 tahun ajaran 2009 yang berjumlah 241 orang. Pemeriksaan kecacingan dengan metode Kato-katz, penentuan status gizi dengan pengukuran berat badan menurut tinggi badan (BB/TB), dan status anemia dengan pengukuran kadar Hb menggunakan metode Cyanmethemoglobin.

Hasil: Hasil penelitian menunjukkan sebagian besar murid (83,6\%) tergolong status gizi baik dan tidak mengalami anemia (84,9\%). Anemia berat tidak ditemukan pada siswa namun terdapat 3 orang (1,3\%) mengalami anemia sedang dan 31 orang $(13,8 \%)$ mengalami anemia ringan. Demikian juga dengan infeksi berat yang tidak ditemukan pada siswa sedangkan 51 siswa yang positif terinfeksi STH menunjukkan derajat keparahan infeksi ringan A. Lumbricoides, T. trichiura, dan Hookworm berturut-turut sebanyak 31,4\%; 70,6\%; dan 5,9\%. Sementara itu, infeksi sedang dari cacing jenis A. Lumbricoides terdapat pada 7 orang (13,7\%) dan T. trichiura sebanyak 8 orang (15,7\%). Hasil uji analisis Somers' $D$ tidak menunjukkan hubungan yang bermakna antara kedua variabel $(p>0,05)$.

Simpulan: Tidak ada hubungan antara tingkat keparahan infeksi STH dengan status gizi dan anemia pada anak sekolah dasar.
\end{abstract}

KATA KUNCI: infeksi Soil Transmitted Helminths, status gizi, anemia

\footnotetext{
${ }^{1}$ Korespondensi: Progam Studi IImu Gizi, Fakultas IImu Kesehatan Universitas Respati Yogyakarta, Jl. Laksda Adisucipto Km 6,3 Depok, Sleman, Yogyakarta, e-mail: farissafatimah@yahoo.co.id

2 Bagian Parasitologi, Fakultas Kedokteran Universitas Gadjah Mada, Jl. Farmako Sekip Utara, Yogyakarta 55281

${ }^{3}$ Bagian IImu Kesehatan Anak, RSUP Dr. Sardjito/Fakultas Kedokteran Universitas Gadjah Mada, JI. Farmako Sekip Utara, Yogyakarta 55281
} 


\section{PENDAHULUAN}

Indonesia merupakan salah satu negara tropis dengan kelembapan tinggi dan mempunyai lingkungan yang baik untuk perkembangbiakan cacing terutama Soil Transmitted Helminths (STH) yaitu nematoda usus yang ditularkan melalui tanah. Beberapa spesies nematoda usus yang sering menginfeksi manusia yaitu Ascaris lumbricoides, Trichuris trichiura, dan Necator americanus. Prevalensi ketiga cacing ini cukup tinggi di daerah pedesaan dan daerah semi urban maupun urban (1). Mereka yang hidup di daerah pedesaan lebih sering terinfeksi daripada yang tinggal di daerah perkotaan (2).

Prevalensi kecacingan di Indonesia masih cukup tinggi dan tersebar luas di pedesaan dan perkotaan. Sekitar $60 \%$ dari 220 juta penduduk Indonesia mengalami kecacingan dan $21 \%$ diantaranya menyerang anak usia sekolah dasar (SD) dengan kerugian lebih dari Rp 500 miliar atau setara dengan 20 juta liter darah per tahun. Hasil survei pada 40 sekolah dasar (SD) di 10 provinsi menunjukkan prevalensi kecacingan berkisar antara 2,2\% - 96,3\% (3). Namun, belum ada data yang menunjukkan prevalensi STH di Indonesia. Hasil Riset Kesehatan Dasar (Riskesdas) tahun 2007 menunjukkan prevalensi nasional Filariasis sebesar $0,11 \%$ dan prevalensi di Daerah Istimewa Yogyakarta (DIY) sebesar 0,03\% (4).

Anak prasekolah dan usia sekolah adalah kelompok risiko tinggi terhadap infeksi STH (5). Di samping itu, anak sekolah juga merupakan salah satu kelompok yang rentan terhadap ketidakcukupan gizi (6). Masalah gizi kurang pada anak usia sekolah akan berlanjut pada masa remaja (7). Berdasarkan hasil penjaringan kesehatan anak SD tahun 2007 menunjukkan bahwa di wilayah kerja Puskesmas Kokap I, anak SD yang status gizinya kurang sebesar $6 \%$ dan mengalami penurunan menjadi sebesar 4,4\% pada tahun 2008 (8). Masalah kurang gizi pada anak dipengaruhi oleh banyak faktor diantaranya adalah infeksi parasit (kecacingan) dan anemia (9).

Selain gizi kurang, anemia merupakan salah satu masalah gizi di Indonesia yang harus ditanggulangi, terutama anemia gizi besi. Hasil Riskesdas menunjukkan prevalensi anemia sebesar 11,9\%. Selain itu, Riskesdas juga menunjukkan nilai rerata nasional kadar hemoglobin (Hb) pada anak-anak yang berumur kurang dari 14 tahun adalah 12,67 g/dl. DIY termasuk dalam 14 provinsi yang mempunyai nilai rerata kadar $\mathrm{Hb}$ di bawah nilai rerata nasional yaitu $12,53 \mathrm{~g} / \mathrm{dl}$ (4). Penyebab anemia gizi besi adalah kurangnya asupan zat besi, kehilangan darah yang kronis, penyakit malaria, cacing tambang, dan infeksiinfeksi lain serta pengetahuan yang kurang tentang anemia zat gizi besi (10).

Infeksi cacing yang ditularkan melalui tanah pada umumnya tidak menyebabkan kematian secara langsung bagi penderita. Namun, infeksi cacing dapat menimbulkan morbiditas yang kompleks karena sifatnya yang menahun. Infeksi cacing mempunyai pengaruh timbal balik dengan keadaan gizi kurang. Derajat atau intensitas sangat mempengaruhi keadaan gizi penderita, semakin berat infeksi maka keadaan gizi penderita semakin buruk, hal ini juga bisa menyebabkan anemia (11). Oleh karena itu, penelitian ini dilaksanakan untuk mengetahui hubungan derajat keparahan infeksi Soil Transmitted Helminths dengan status gizi dan anemia pada anak SD di wilayah kerja Puskesmas Kokap I Kabupaten Kulonprogo yang merupakan wilayah pegunungan dengan keadaan tanah sebagian besar lembap sebagai tempat yang baik untuk pertumbuhan cacing.

\section{BAHAN DAN METODE}

Jenis penelitian ini adalah observasional dengan rancangan penelitian cross sectional. Penelitian dilaksanakan pada bulan Oktober - Desember 2009 di SD yang berada di wilayah kerja Puskesmas Kokap I, Kecamatan Kokap, Kabupaten Kulonprogo, Provinsi DIY. Populasi dalam penelitian ini adalah seluruh siswa kelas satu pada tahun ajaran 2009/2010 yang tercatat di 25 sekolah dasar di wilayah kerja Puskesmas Kokap I sebanyak 241 orang. Sampel penelitian diperoleh sebanyak 225 siswa yang dipilih menggunakan metode accidental sampling atau convenience sampling yaitu seluruh populasi penelitian yang hadir saat penelitian dilaksanakan dan mengumpulkan pot tinja. Pengambilan sampel ini berdasarkan latar belakang prevalensi tertinggi T. trichiura pada anak usia 5-15 tahun dan A. lumbricoides pada usia 5-9 tahun (12).

Pengumpulan tinja dilakukan melalui pot tinja yang dibawa pulang oleh siswa untuk digunakan sebagai tempat menyimpan sampel tinja pada saat buang air besar keesokan harinya, kemudian dibawa ke sekolah untuk dilakukan pemeriksaan kecacingan. Pemeriksaan tinja menggunakan metode Kato-Katz (3) yang dilakukan oleh petugas laboratorium Puskesmas Kokap I. Pemeriksaan tidak hanya bersifat kualitatif yaitu mengetahui ada tidaknya telur cacing tetapi juga secara kuantitatif dengan menghitung jumlah rata-rata telur per gam tinja. Intensitas infeksi kecacingan dibedakan menjadi tiga yaitu ringan, sedang, dan berat menurut jenis cacing (Tabel 1) (3).

Tabel 1. Klasifikasi intensitas infeksi menurut jenis cacing

\begin{tabular}{cccc}
\hline \multirow{2}{*}{ Klasifikasi } & \multicolumn{3}{c}{ Jumlah telur per gram tinja } \\
\cline { 2 - 4 } & $\begin{array}{c}\text { Cacing } \\
\text { gelang }\end{array}$ & $\begin{array}{c}\text { Cacing } \\
\text { cambuk }\end{array}$ & $\begin{array}{c}\text { Cacing } \\
\text { tambang }\end{array}$ \\
\hline Ringan & $1-4.999$ & $1-999$ & $1-1.999$ \\
Sedang & $5.000-49.999$ & $1.000-9.999$ & $2.000-3.999$ \\
Berat & $\geq 50.000$ & $\geq 10.000$ & $\geq 4.000$ \\
\hline
\end{tabular}

Sumber: Departeman Kesehatan RI, 2006 (3) 
Pengukuran antropometri berupa berat badan (BB) menggunakan alat ukur timbang badan digital merk Camri (ketelitian 0,1 kg) dan tinggi badan (TB) menggunakan microtoise (ketelitian 0,1 cm) yang dilakukan satu kali saat penelitian berlangsung. Pengukuran antropometri dilakukan oleh peneliti dibantu seorang petugas gizi Puskesmas Kokap I dengan alat yang sama untuk seluruh subjek penelitian. Hal ini dilakukan agar hasil yang diperoleh tidak menyimpang karena alat ukur dan cara pengukurannya dikendalikan.

Hasil pengukuran berat badan dan tinggi badan kemudian dibandingkan dengan indikator BB/TB melalui persen terhadap median dengan standar deviasi unit atau z-skor berdasarkan baku rujukan World Health Organization National Center for Health Statistics (WHO-NCHS) (13). Hasil pengukuran diklasifikasikan berdasarkan z-skor WHO-NCHS menggunakan Kartu Menuju Sehat (KMS) anak sekolah dasar yang telah dibedakan untuk laki-laki yang berwarna biru muda dan perempuan yang berwarna merah muda. Jika titik perpotongan antara berat badan dan tinggi badan berada di bawah persentil 3 (P3) maka anak diklasifikasikan gizi kurang, jika berada di antara persentil 3-97 (P3-P97) diklasifikasikan menjadi gizi baik, dan jika berada di atas P97 diklasifikasikan gizi lebih. Program penggunaan Kartu Menuju Sehat (KMS) Anak Sekolah Dasar dan Madrasah Ibtidaiyah dikeluarkan oleh Departemen Kesehatan RI, Direktorat Jenderal Kesehatan Masyarakat, Direktorat Gizi Masyarakat pada tahun 2002 yang digandakan oleh Dinas Kesehatan Kabupaten Kulonprogo pada tahun 2008 dan diberikan oleh Puskesmas Kokap I kepada seluruh siswa SD di wilayah kerjanya. Dengan adanya KMS, perkembangan anak dapat dipantau secara praktis, sederhana, dan mudah.

Penilaian status anemia melalui pemeriksaan kadar $\mathrm{Hb}$ darah dengan metode Cyanmethaemoglobin (13). Siswa dikaterogikan tidak anemia atau normal jika kadar $\mathrm{Hb}$ lebih dari atau sama dengan $11,5 \mathrm{~g} / \mathrm{dl}$ (13). Siswa yang kadar $\mathrm{Hb}$-nya di bawah normal dikategorikan anemia dan diklasifikasikan berdasarkan derajat anemia yaitu berat (<8 g/dl), sedang (8-9 g/dl), dan ringan (10-11 g/dl) (13). Analisis yang digunakan untuk melihat ada atau tidaknya hubungan dan kekuatan hubungan antar variabel adalah analisis uji korelasi non parametrik Somers'D (tingkat kepercayaan 95\%) karena semua data berupa variabel kategorikal (skala ordinal) dengan distribusi tidak normal. Penelitian ini telah mendapatkan kelayakan etik dari Komisi Etik Penelitian Kedokteran dan Kesehatan Fakultas Kedokteran Universitas Gadjah Mada.

\section{HASIL}

\section{Karakteristik subjek penelitian}

Sebagian besar subjek berusia 5-6 tahun $(66,4 \%)$ dan berdasarkan jenis kelamin didapatkan lebih banyak siswa laki-laki $(53,3 \%)$ (Tabel 2).
Tabel 2. Karakteristik subjek penelitian

\begin{tabular}{lcc}
\hline \multicolumn{1}{c}{ Karakteristik } & $\begin{array}{c}\text { Jumlah } \\
(\mathbf{n = 2 2 5})\end{array}$ & $\begin{array}{c}\text { Persentase } \\
(\mathbf{\%})\end{array}$ \\
\hline Usia (tahun) & & \\
$5-6$ & 144 & 66,4 \\
$7-8$ & 79 & 32,8 \\
$9-10$ & 2 & 0,8 \\
Jenis kelamin & & \\
Laki-laki & 120 & 53,3 \\
Perempuan & 105 & 46,7 \\
\hline
\end{tabular}

Tabel 3. Status gizi dan anemia subjek penelitian

\begin{tabular}{lcc}
\hline \multicolumn{1}{c}{ Karakteristik } & $\begin{array}{c}\text { Jumlah } \\
(\mathbf{n = 2 2 5})\end{array}$ & $\begin{array}{c}\text { Persentase } \\
(\mathbf{\%})\end{array}$ \\
\hline Status gizi & & \\
Kurang & 28 & 12,4 \\
Baik & 188 & 83,6 \\
Lebih & 9 & 4,0 \\
Status anemia & & \\
Anemia & & \\
$\quad$ Berat & 0 & 0 \\
$\quad$ Sedang & 3 & 1,3 \\
$\quad$ Ringan & 31 & 13,8 \\
Non anemia & 191 & 84,9 \\
\hline
\end{tabular}

\section{Status gizi dan anemia}

Hasil pengukuran status gizi menunjukkan sebagian besar subjek $(83,6 \%)$ tergolong status gizi baik dan tidak anemia $(84,9 \%)$ (Tabel 3). Penilaian status anemia secara mikrositik melalui apusan darah tepi tidak dapat dilakukan karena pada pemeriksaan kadar $\mathrm{Hb}$ nilai terendah diperoleh 9,6 g/dl yang termasuk kategori sedang. Biasanya apusan darah tepi memperlihatkan gambaran normokromik normositik tetapi pada tahap yang lebih lanjut sel-sel dapat menjadi hipokromik dan mikrositik. Mikrositosis biasanya tidak separah pada anemia defisiensi besi dan jarang dijumpai, tingkat keparahan biasanya sedang dengan kadar $\mathrm{Hb}$ 7-11 g/dl (14).

\section{Pemeriksaan tinja}

Hasil pemeriksaan tinja menunjukkan bahwa diperoleh 51 anak (22,7\%) yang positif terinfeksi STH dan 174 anak $(77,3 \%)$ negatif. Hasil penelitian menunjukkan bahwa terjadi infeksi STH pada siswa dengan berbagai kondisi, baik infeksi oleh satu jenis cacing maupun infeksi oleh dua bahkan tiga jenis cacing. Siswa yang terinfeksi satu jenis cacing sebanyak 32 orang $(62,8 \%)$ dengan jenis cacing $A$. lumbricoides sebanyak 7 orang (13,7\%), T. trichiura sebanyak 25 orang $(49,1 \%)$, dan tidak ada siswa yang terinfeksi Hookworm saja. Sementara itu, siswa yang terinfeksi dua jenis cacing sebanyak 18 orang $(35,3 \%)$ dengan jenis cacing yang menginfeksi adalah $A$. lumbricoides dan T. trichiura sebanyak 15 orang $(29,4 \%)$, 
Tabel 4. Intensitas infeksi STH menurut jenis cacing

\begin{tabular}{ccccccc}
\hline Intensitas & \multicolumn{2}{c}{$\boldsymbol{A}$. lumbricoides } & \multicolumn{2}{c}{ T. trichiura } & \multicolumn{2}{c}{ Hookworm } \\
\cline { 2 - 7 } infeksi & $\mathbf{n}$ & $\%$ & $\mathbf{n}$ & $\%$ & $\mathbf{n}$ & $\%$ \\
\hline Ringan & 16 & 31,4 & 36 & 70,6 & 4 & 5,9 \\
Sedang & 7 & 13,7 & 8 & 15,7 & 0 & 0 \\
Berat & 0 & 0 & 0 & 0 & 0 & 0 \\
Negatif & 28 & 54,9 & 7 & 13,7 & 47 & 94,1 \\
\hline
\end{tabular}

T. trichiura dan Hookworm sebanyak tiga orang $(5,9 \%)$, dan tidak ada siswa yang terinfeksi $A$. lumbricoides dan Hookworm. Siswa yang terinfeksi tiga jenis cacing yaitu $A$. lumbricoides, T. trichiura, dan Hookworm sebanyak satu orang $(1,9 \%)$.

Hasil penelitian menunjukkan bahwa dari 51 siswa yang positif terinfeksi STH, berdasarkan intensitas infeksinya diperoleh subjek yang termasuk kriteria infeksi ringan A. lumbricoides, T. trichiura, dan Hookworm berturut-turut sebanyak 31,4\%; 70,6\%; dan 5,9\%. Kriteria infeksi sedang hanya pada cacing jenis $A$. lumbricoides $(13,7 \%)$ dan $T$. trichiura (15,7\%) sedangkan infeksi berat tidak ditemukan (Tabel 4).

\section{Hubungan infeksi STH dengan status gizi dan anemia}

Hasil analisis dengan uji Somers'D, menunjukkan hubungan yang tidak bermakna antara status gizi dengan infeksi STH $(p>0,05)$ sehingga dapat disimpulkan bahwa derajat keparahan $A$. lumbricoides dan $T$. trichiura tidak berhubungan dengan status gizi ( $p=0,310$ dan $p=0,790$ ). Sementara itu, subjek yang terinfeksi Hookworm semua dalam derajat ringan dengan status gizi baik sebanyak 3 orang $(75 \%)$ dan 1 orang (25\%) status gizi kurang. Demikian juga hasil uji Somers'D antara anemia dengan infeksi STH yang menunjukkan bahwa derajat keparahan A. lumbricoides dan T. trichiura tidak berhubungan dengan anemia $(p=0,825$ dan $p=0,584)$ sedangkan subjek yang terinfeksi Hookworm semua dalam derajat ringan dengan status tidak anemia sebanyak 3 orang (75\%) dan 1 orang $(25 \%)$ anemia derajat ringan.

\section{BAHASAN}

\section{Status gizi dan anemia}

Secara keseluruhan siswa SD di wilayah kerja Puskesmas Kokap I berada dalam status gizi baik meskipun terdapat beberapa siswa terinfeksi STH. Hal ini bisa terjadi kemungkinan karena penentuan status gizi menggunakan BB/TB yang memiliki kelemahan tidak sensitif terhadap perubahan kecil yaitu dalam keadaan normal perkembangan berat badan akan searah dengan pertumbuhan tinggi badan dengan kecepatan tertentu (13).
Hal ini sejalan dengan hasil penelitian di Kecamatan Indra Jaya, Aceh yang menunjukkan secara keseluruhan status gizi siswa $\mathrm{SD}$ tergolong normal dengan menggunakan indikator BB/TB walaupun intensitas infeksi cacing ususnya sangat tinggi. Ascariasis dan Trichuriasis memang terbukti menyebabkan terjadinya gangguan absorbsi dan digesti zat-zat makanan, tetapi pengaruhnya terhadap keadaan gizi penderita relatif kecil karena banyak faktor-faktor lain yang turut berpengaruh pada status gizi seseorang. Asupan makanan menjadi faktor utama yang mempengaruhi status gizi yang dibuktikan oleh hasil penelitian di Kecamatan Indra Jaya, Aceh yaitu normalnya status gizi siswa sekolah dasar berhubungan secara bermakna dengan asupan makanan (15).

Sementara itu, hasil penelitian ini juga menunjukkan bahwa sebagian besar siswa tidak mengalami anemia. Berbeda dengan hasil penelitian pada murid SD di Kota Mataram yang menyatakan bahwa sebagian besar siswa menderita anemia $(83,73 \%)$ dan hal ini sudah berlangsung lama berdasarkan laporan instansi terkait. Hal tersebut terjadi karena pelaksanaan progam pemberantasan anemia yang dilakukan berupa pemberian tambahan Fe untuk anak sekolah tidak bisa berjalan secara berkesinambungan (16). Anak SD adalah salah satu subjek yang berisiko paling besar untuk menderita anemia, tetapi sebagian besar anemia ini adalah anemia ringan dan merupakan sebuah konsekuensi ringan dari kesehatan karena beberapa mekanisme kompensasi seperti output jantung meningkat, pengalihan aliran darah ke organ vital tubuh dan oksigen dari $\mathrm{Hb}(17)$.

\section{Infeksi dan intensitas Soil Transmitted Helminths}

Hasil penelitian pada murid SD di Kota Mataram menunjukkan angka tertinggi infeksi positif terjadi pada dua jenis cacing $(81,89 \%)$ (16). Hal ini berbeda dengan hasil penelitian ini yang menemukan angka tertinggi infeksi positif terjadi pada satu jenis cacing $(62,8 \%)$. Namun, prevalensi tertinggi penelitian tersebut sejalan dengan penelitian ini yaitu terjadi pada infeksi $T$. trichiura diikuti A. lumbricoides, dan Hookworm. Hasil penelitian di Petojo Selatan, Jakarta Pusat juga mendukung hasil penelitian ini yaitu infeksi kecacingan tertinggi terjadi pada T. trichiura $(94,7 \%)$, A. lumbricoides $(81,8 \%)$, dan Hookworm $(0,37 \%)$ (18). Sejalan pula dengan penelitian pada anak SD di Kecamatan Indra Jaya, Aceh yang menunjukkan prevalensi tertinggi T. trichiura (86,66\%), diikuti A. lumbricoides (85,71\%), dan Hookworm (9,52\%) (15). Apabila dibandingkan dengan penelitian lain sebelumnya, ada perbedaan pola infeksi seperti penelitian yang dilakukan di Lombok Timur pada dua SD yaitu prevalensi tertinggi pada $A$. lumbricoides $(96,6 \%$ dan $73,5 \%)$ kemudian diikuti prevalensi $T$. trichiura $(79,4 \%$ dan $69,0 \%$ ) (19). Perbedaan prevalensi tertinggi di antara 
beberapa tempat tersebut karena adanya perbedaan faktor geogafis yaitu cacing $A$. lumbricoides dan T. trichiura lebih senang tinggal di tanah liat dengan lingkungan yang hangat dan lembap sedangkan Hookworm senang tumbuh di tanah yang gembur (20).

Pada umumnya infeksi cacing tidak menyebabkan kematian secara langsung pada penderitanya, tetapi dapat menimbulkan anoreksia (hilang nafsu makan) dan gangguan absorbsi zat gizi disamping menimbulkan destruksi kronik yang pada gilirannya akan menyebabkan kurang gizi (21). Pengaruh infeksi cacing tambang terhadap timbulnya anemia sudah banyak dibahas (11, 22). Beberapa penelitian mendapatkan derajat kurang gizi dan anemia sebagai akibat infeksi STH searah dengan intensitas keparahan infeksi masing-masing jenis cacing $(23,12)$.

\section{Hubungan derajat keparahan Soil Transmitted Helminths dengan status gizi}

Infeksi cacing menyebabkan penderita kurang nafsu makan, menurunnya asupan zat gizi, gangguan pada saluran pencernaan, dan gangguan absorbsi makanan sehingga terjadi defisiensi zat gizi (18). Hasil analisis menunjukkan hubungan yang tidak bermakna antara status gizi dengan derajat keparahan STH. Hasil penelitian ini sejalan dengan penelitian di Kota Mataram yang menunjukkan tidak adanya hubungan yang bermakna antara prevalensi dan intensitas kecacingan (A. lumbricoides, T. trichiura, dan Hookworm) dengan status indeks massa tubuh (IMT). Pada penelitian tersebut, 90\% siswa menderita kurang energi kronis (KEK) yang kemungkinan disebabkan oleh rendahnya asupan gizi (16). Sejalan pula dengan penelitian di Aceh yang menunjukkan hasil yaitu tidak adanya hubungan yang bermakna antara intensitas infeksi cacing usus dengan status gizi siswa SD (Spearman $r=-0,131 ; p=0,148$ dan Kendall $t=0,183$; $\mathrm{p}=0,183)(15)$.

Hasil penelitian ini menunjukkan intensitas infeksi kecacingan yang rendah sehingga tidak berpengaruh terhadap status gizi. Hal ini sesuai dengan penelitian yang menyebutkan bahwa tidak ada hubungan bermakna antara infeksi cacing tambang dengan status gizi terutama pada infeksi ringan (24). Dari beberapa literatur disebutkan bahwa intensitas kecacingan yang dapat berpengaruh terhadap status gizi adalah kecacingan derajat berat (12), padahal hasil penelitian ini tidak ditemukan siswa dengan infeksi kecacingan derajat berat. Pada penelitian ini infeksi kecacingan merupakan infeksi baru yang ditemukan pada siswa, hal ini mungkin belum memberikan pengaruh terhadap status gizi. Selain itu, pada penelitian ini infeksi kecacingan diteliti bersamaan dengan pengukuan status gizi, hal ini juga memungkinkan infeksi kecacingan belum memberikan pengaruh terhadap status gizi.
Berbeda dengan hasil penelitian di Semarang yang menunjukkan adanya kecenderungan bahwa mereka yang terinfeksi ganda, tanpa harus menilai keparahan infeksi masing-masing jenis cacing penyebab, akan mendapatkan akibat yang lebih parah dibandingkan mereka yang terinfeksi tunggal atau tidak terinfeksi ganda (25). Infeksi T. trichiura pada derajat berat dapat mengurangi nafsu makan sehingga menyebabkan penurunan berat badan dan infeksi serius pada anak-anak yang selalu berakhir dengan malnutrisi. Infeksi Hookworm dapat menyebabkan penderita mengalami malnutrisi pada keadaan infeksi kronis sedangkan infeksi kronis yang terjadi pada anakanak dapat menimbulkan gangguan pertumbuhan dan kemunduran mental. Infeksi $A$. lumbricoides derajat ringan hanya menimbulkan perasaan tidak enak di perut, tetapi pada infeksi berat dapat timbul gejala mual, muntah, dan anoreksia yang berpengaruh terhadap status gizi dan berakhir pada malnutrisi (2).

Meskipun demikian, belum dapat dikatakan pula bahwa infeksi cacing adalah penyebab terjadinya penurunan status gizi karena derajat endemisitas turut berperan secara tidak langsung pada status gizi. Tingkat pengaruh infeksi cacing terhadap status gizi tergantung pada berat ringannya infeksi, jenis cacing usus yang menginfeksi, serta tingkat endemik lingkungan tempat tinggal (26). Pada penelitian ini sebagian besar siswa terinfeksi $A$. lumbricoides, T. trichiura, dan Hookworm derajat ringan dan tidak ada siswa yang terinfeksi derajat berat sehingga pada populasi penelitian ini tidak tampak hubungan antara status gizi dengan derajat keparahan STH.

\section{Hubungan derajat keparahan Soil Transmitted Helminths dengan anemia}

Hasil analisis menunjukkan anemia tidak mempunyai hubungan yang bermakna dengan derajat keparahan STH. Hal ini mungkin karena tidak semua jenis STH menyebabkan anemia, hanya infeksi $T$. trichiura dan Hookworm dalam tahap infeksi berat yang dapat menimbulkan anemia sedangkan pada penelitian ini tidak ditemukan infeksi berat pada semua jenis cacing.

Hasil penelitian ini menunjukkan infeksi T. trichiura tidak berhubungan dengan anemia. Infeksi ringan oleh cacing ini biasanya tidak menimbulkan gejala, tetapi infeksi berat dengan 100 ekor cacing akan menimbulkan beberapa gejala diantaranya anemia (2). Demikian pula dengan infeksi Hookworm pada penelitian ini tidak berhubungan dengan anemia. Seekor cacing dapat menghisap 0,03-0,15 $\mathrm{ml}$ darah per hari yang bila keadaan ini berlangsung lama akan menyebabkan anemia. Namun, gejala yang timbul sangat tergantung pada jumlah cacing yang menginfeksi, lamanya infeksi, daya tahan tubuh, dan status gizi penderita (2). Pada penelitian ini prevalensi dan intensitas infeksi cacing tergolong rendah, namun lamanya infeksi 
tidak dapat diketahui karena penderita yang terinfeksi tidak diikuti perkembangannya dan data diambil pada waktu bersamaan. Selain itu, status gizi sebagian besar subjek pada saat pengambilan data tergolong baik.

Lebih jauh lagi, sebagian besar wilayah kerja Puskesmas Kokap I merupakan wilayah dataran tinggi yang memungkinkan terjadinya polisitemia yaitu kelebihan sel darah merah dalam sirkulasi sehingga terjadi peningkatan kemampuan darah mengangkut oksigen. Keadaan ini timbul secara normal pada orang yang tinggal di dataran tinggi yaitu pada keadaan lebih sedikit oksigen yang tersedia di atmosfer (27). Dalam hal ini, polisitemia disebut polisitemia sekunder atau polisitemia fisiologis yaitu jumlah sel darah merah umumnya naik sekitar 30\% di atas normal. Kenaikan volume ini mengakibatkan viskositas darah sangat meningkat dan aliran darah yang melalui pembuluh perifer seringkali menjadi sangat lambat (28). Pada penelitian ini, kemungkinan terjadi penurunan kadar $\mathrm{Hb}$ akibat infeksi STH, tetapi akibat adanya polisitemia maka kadar $\mathrm{Hb}$ tetap berada pada batas normal sehingga tidak terlihat hubungan yang bermakna antara anemia dengan derajat keparahan infeksi STH.

\section{SIMPULAN DAN SARAN}

Tidak ada hubungan yang bermakna antara derajat keparahan infeksi Soil Transmitted Helminths dengan status gizi dan anemia pada anak SD di wilayah kerja Puskesmas Kokap I, Kabupaten Kulonprogo terutama disebabkan oleh infeksi yang terjadi tergolong ringan. Oleh karena itu, perlu adanya pemeriksaan infeksi Soil Transmitted Helminths secara rutin yang dilakukan untuk menemukan kasus baru, kemudian dilakukan penanganan sesuai progam yang ada di Puskesmas baik itu berupa pengobatan maupun penyuluhan tentang perilaku hidup bersih dan sehat (PHBS) dalam upaya pencegahan infeksi. Perlu dilakukan penelitian lebih lanjut tentang faktor-faktor lain yang mungkin berhubungan dengan infeksi Soil Transmitted Helminths yang belum diteliti pada penelitian ini yaitu lamanya infeksi dan daya tahan tubuh.

\section{RUJUKAN}

1. Rukmono B. Penyakit cacing yang ditularkan melalui tanah dan pemberantasannya. Medika 1980;6(3):12935.

2. Bernardus S. Parasitologi kedokteran, helminthologi kedokteran buku-2. Jakarta: Prestasi Pustaka; 2007.

3. Depkes RI. Keputusan Menteri Kesehatan Nomor: 424/MENKES/SK/VI/2006 mengenai pedoman pengendalian cacingan. [serial online] 2006 [cited 2009 August 3]. Available from: URL: http.//www.depkes. go.id/downloads/Kepmenkes

4. Badan Penelitian Pengembangan Kesehatan. Laporan hasil riset kesehatan dasar (Riskesdas) Indonesia - tahun 2007. Jakarta: Departemen Kesehatan Republik Indonesia; 2008.

5. Knopp S, Mgeni AF, Khamis IS, Steinmann P, Stothard JR, Rollinson D, Marti H, Utzinger J. Diagnosis of soil-transmitted helminths in the era of preventive chemotherapy: effect of multiple stool sampling and use of different diagnostic techniques. PLoS Negl Trop Dis 2008;2(11):e331.

6. Sediaoetama AD. IImu gizi: untuk mahasiswa dan profesi. Jakarta: PT Dian Rakyat; 2006.

7. ADB Nutrition and Development Series. Effectiveness of large scale nutrition intervention. ACC/SCN Nutrition Policy Paper 2001;19.

8. Almatsier S. Prinsip dasar ilmu gizi. Jakarta: PT Gamedia Pustaka Utama; 2004.

9. Puskesmas Kokap I Kabupaten Kulonprogo. Profil Puskesmas Kokap I tahun 2008. Yogyakarta: Provinsi Daerah Istimewa Yogyakarta; 2009.

10. De Maeyer EM. Pencegahan dan pengawasan anemia defisiensi besi. Jakarta: Penerbit Widya Medika; 1995.

11. Tantular K. Anemia pada penyakit cacing tambang dan usaha penanggulangannya. Seminar Sehari Masalah dan Penanggulangan Infeksi Soil Transmitted Helminths di Indonesia; 1998; Surabaya.

12. Sandjaja B. Nematoda dalam parasitologi kedokteran, helminthologi kedokteran buku-2. Jakarta: Prestasi Pustaka; 2007.

13. Supariasa IN, Bakri B, Fajar I. Penilaian status gizi. Jakarta: EGC; 2002.

14. Sacher RA, McPherson RA. Tinjauan klinis hasil pemeriksaan laboratorium, edisi 11. Jakarta: EGC; 2004.

15. Efendi. Perilaku hidup sehat, intensitas infeksi cacing usus dan status gizi siswa sekolah dasar di Kecamatan Indra Jaya Kabupaten Pidie, Nanggo Aceh Darussalam [Tesis]. Yogyakarta: Progam Pascasarjana Universitas Gadjah Mada; 2002.

16. Hidayat T. Kesehatan lingkungan, higiene perseorangan dan intensitas penyakit kecacingan dengan status gizi pada anak sekolah dasar di Kota Mataram [Tesis]. Yogyakarta: Progam Pascasarjana Universitas Gadjah Mada; 2002.

17. Thurnham DI, Northrop-clwes CA. Infection and the etiology anemia. In: Kraemer K, Zimmermann MB, editors. Nutritional anemia. Switzerland: Sight and Life Press; 2007.

18. Alisah S, Abidin N, Sunkar S. Beberapa infeksi parasit massa lampau dan masa kini di Indonesia. Majalah Kedokteran Indonesia 1997;47(9):453-454.

19. Margono SS, Sukardi W, Ismid IS, Abidin SAN. Soil Transmitted Helminths in primary school children in sorroundings of a sanitation clinic in East Lombok, West Nusa Tenggara. Presented at the $22^{\text {nd }}$ APCO Parasitologists Meeting; 2000; Tokyo, Jepang. 
20. Gandahusada S, Illahude DH, Pribadi W. Helmintologi dalam parasitologi kedokteran, edisi ketiga. Jakarta: Balai Penerbit Fakultas Kedokteran Universitas Indonesia; 2006.

21. Latham M. A priority for primary health care. Proceedings of a Workshop "Intestinal Parasites: A Priority for Primary Health Care". New York: Cornell University; 1991.

22. Soemantri GAW. Hubungan anemia kekurangan zat besi dengan konsentrasi dan prestasi belajar [Disertasi]. Semarang: Universitas Diponegoro; 1987.

23. Cline B. Impact of intestinal on human health. Proceedings of a Workshop "Intestinal Parasites: A Priority for Primary Health Care". New York: Cornell University; 1991.
24. Hardiana T, Hertanto WS, Rahfiludin MZ. Hubungan infeksi cacing tambang derajat ringan dengan kesegaran jasmani, status gizi dan kadar $\mathrm{Hb}$ murid sekolah dasar. Majalah Penelitian 2000;XII(45).

25. Subagio HW, Hendratno S, Satoto. Keadaan gizi, kadar hemoglobin, dan potensi belajar anak sekolah dasar pengidap ringan infeksi cacing tambang. Semarang: FK UNDIP; 1998.

26. Enoch M, Syafrudin, Suhatati. Status gizi dan infeksi cacing usus di sekolah dasar di Pekalongan. Medika 1994;20(3):21-5.

27. Sherwood L. Fisiologi manusia: dari sel ke sistem, edisi 2. Jakarta: EGC; 2001.

28. Guyton AC, Hall JE. Buku ajar fisiologi kedokteran, edisi 11. Jakarta: EGC; 2008. 